\title{
A Novel Country Classification System for Choosing International Business Locations
}

\author{
Mikidadu Mohammed $^{1} \&$ Jean Marie Luundo ${ }^{1}$ \\ ${ }^{1}$ Department of Economics \& Business Administration, Austin College, Texas, U.S.A. \\ Correspondence: Mikidadu Mohammed, Department of Economics \& Business Administration, Austin College, \\ 900 North Grand Avenue, Sherman, Texas 75090, U.S.A.
}

Received: October 28, 2019

Accepted: November 22, 2019

Online Published: November 26, 2019

doi:10.5539/ibr.v13n1p29

URL: https://doi.org/10.5539/ibr.v13n1p29

\begin{abstract}
This paper introduces a novel country classification system that rates the political economy risks of countries for the purpose of conducting international business. It is intended to provide investors, multinational companies, and business researchers a quick and efficient way of gauging the extent of political, economic, and legal risks associated with doing business in different countries. The study covers over 170 countries and identifies 24 country types. At the extremes are Type 1 countries (least risky) and Type 24 countries (most risky). Overall, the new classification system suggests that political economy risks associated with doing international business are relatively mild in Type 1, Type 3, and Type 4 countries. However, international businesses should temper their investment decisions with caution in Type 19, Type 20, Type 22, Type 23, and Type 24 countries due to high political, economic, and legal risks, especially Types 23 and 24 where these risks are excessive. At the same time, international businesses may want to refocus their attention to Type 11 countries who are now havens for international investments due to drastic reduction in political, economic, and legal risks associated with doing business. The twenty-four country types identified in this new classification system are time-invariant. Thus, countries may move up or down due to improvements or deteriorations in certain aspects of their political economy.
\end{abstract}

Keywords: legal, international business, political, economic, risks, classification

\section{Introduction}

Countries have different political, economic, and legal systems. In each country, these systems collectively constitute the political economy. Political economy of a country can either facilitate or hinder multinational companies' ability to conduct business in that country (Gomez and Jomo 1999; Hamilton and Webster 2018; Haggard 2000; Henisz and Zelner 2003; Hill 2016). While international businesses repeatedly demand multifaceted information about the political, economic, and legal systems of countries, existing country classifications treat these systems as mutually exclusive and categorize countries based on one system at a time (Ball 1988; Brooker 2000; Collier 1999; Heilbroner and Boettke 2018; Economist Intelligence Unit 2019; Juri Globe 2019). For instance, Brooker (2000) focuses on political systems and distinguishes between non-democratic and democratic regimes. Heilbroner and Boettke (2018) focus on economic systems and classify countries into free market systems and centrally planned systems. Juri Globe (2019) focuses on legal systems and categorizes countries into five different legal systems. These siloed classification systems, though useful in some settings, are often fragmented and inefficient for international businesses. For instance, if a business in one country plans to expand its operations into another country, the business has to scramble for information from copious sources to determine the nature of political economy of that country and associated risks. The time and resources used to sift through these fragmented sources of information ultimately increases transaction costs.

The purpose of any classification system is to allow users to access information in an efficient and timely manner with the least amount of frustration as possible (Bruno and Richmond 2003). Thus, the goal of this paper is to reorganize the existing siloed classification systems to develop a more composite country classification system based on the political economy of countries. In particular, the study proposes a simple framework that classify countries depending, simultaneously, on the type of political, economic, and legal systems to provide international businesses a quick and efficient way of gauging the extent of political, economic, and legal risks associated with doing business in different countries. 
The rest of the paper is organized as follows. Section 2 discusses the different political, economic, and legal systems. Section 3 describes the methodology for classifying countries. Results from the classification system are also presented and discussed in Section 3. Section 4 concludes.

\section{Political, Economic, and Legal Systems}

\subsection{Political Systems}

The political system of a country is the set of formal institutions that constitute a government or a state (Heslop 2018). The most common political systems are republic, democracy, monarchy, communism, and totalitarianism. Some are variants of others (democracy from republics) while others are antithesis to others (totalitarianism antithesis to democracy). Furthermore, each has its strengths and weaknesses and possess different types of risks and challenges to international businesses.

Because globally countries are moving towards democracy, the political system of a country is often defined by the extent of democratic principles prevailing in that country. The Economist Intelligence Unit Democracy Index (EIU-DI) provides a snapshot of the current state of democracy worldwide for 167 independent countries. This covers almost the entire population of the world and the vast majority of the world's countries. The EIU-DI is based on five categories: electoral process and pluralism, civil liberties, the functioning of government, political participation, and political culture. Based on a country's scores on a range of indicators within these categories, the country is then itself classified as one of four types of regimes: full democracy, flawed democracy, hybrid regime, and authoritarian regime. Full democracies are countries in which basic political freedoms and civil liberties are respected. Full democracies are also characterized by a political culture conducive to the flourishing of democratic principles. Flawed democracies are countries that have free and fair elections. Even if there are problems (such as infringements on media freedom), basic civil liberties are respected. Hybrid regimes are countries in which elections have substantial irregularities that often prevent them from being both free and fair. Also, government pressure on opposition parties and candidates may be common. In countries with authoritarian regimes, political pluralism is absent or heavily curtailed. Many countries in this category are outright dictatorships. ${ }^{1}$

In this study, we used the EIU-DI (2019) to define the degrees of democracy, i.e., more democratic and less democratic. More democratic countries are full democracies plus flawed democracies. Less democratic countries includes hybrid regimes and authoritarian regimes. Political systems of 11 countries are not included in the EIU-DI. These countries are Greenland, Somalia, South Sudan, Falkland Islands, Grenada, Kiribati, Cape Verde, Vatican, Andorra, Western Sahara, and Kosovo. Thus, we rely on data from the 2019 CIA World Factbook (CIAWFB) to determine their respective political systems. According the CIAWFB (2019), the political system of South Sudan is in transition. For this reason, it is not included in the list. Also excluded from the list are the disputed territories of Western Sahara. Table 1 reports the list of 176 countries based on our simplified definition of political systems (more or less democratic).

\subsection{Economic Systems}

The study defines economic systems based on the degree of individual or government involvement in economic decision making. Thus, economic system is synonymous to the degree of freedom in a country. Relying on Freedom Houses Freedom in the World (FH-FIW) classification, we parsed countries into market economy (free), command economy (not free), and mixed economy (partially free). The data comes from the Freedom House (2019) FIW report which evaluates the state of freedom in 195 countries and 14 territories during calendar year 2018. Each country and territory is assigned between 0 and 4 points on a series of 25 indicators, for an aggregate score of up to 100. These scores are used to determine two numerical ratings, for political rights and civil liberties, with a rating of 1 representing the freest conditions and 7 the least free. A country or territory's political rights and civil liberties ratings then determine whether it has an overall status of free, partly free, or not free. The methodology is derived from the Universal Declaration of Human Rights and applied to all countries and territories, irrespective of geographic location, ethnic or religious composition, or level of economic development. ${ }^{2}$ Comoros, Fiji, and Hong Kong are not included in the FH-FIW index. Thus, we used data from globalEDGE (2019) to determine their economic systems. Table 2 reports the list of countries by economic systems.

\subsection{Legal Systems}

Generally, there are three types of legal systems: common law, civil law, and theocratic law. Common law is based on tradition, precedent, and custom (Hill 2016). It is derived from the English common law and is found in many parts of the English-speaking world such as Australia, Canada, England, the United States, Wales, and 
other countries (Sjuggerud 2018). Civil law is based on a detailed set of laws organized into codes. Its origin can be traced to Roman law and is found today in much of continental Europe, Central America, South America, and several other regions. Nations with civil law systems have comprehensive, frequently updated legal codes (USC Law 2019). Theocratic law is a legal system predominantly based on religious teachings. Islamic law (or Sharia law) is the most widespread theocratic law found in varying degrees in some countries in Africa, the Middle East, Central Asia, and South Asia. Other theocratic law systems include the Jewish law (Israel) and Christian law (Vatican).

Building on the three primary types of legal systems, JuriGlobe (2019), the most comprehensive world legal systems database defines five categories of legal systems: common law, civil law, customary law, religious law and mixed law systems; the latter referring to a combination of systems. Because customary laws are typically a subset of common law which broadly encompasses tradition, precedent, and patterns of behavior or customs, we combine customary law with common law and reclassify JuriGlobe's five legal systems into four: common law, civil law, theocratic law, and mixed components law system. Table 3 reports the country classification based on the four legal systems. ${ }^{3}$

Table 1. Political Systems (by country)

\begin{tabular}{|c|c|c|c|c|c|}
\hline \multicolumn{3}{|l|}{ More Democratic } & \multicolumn{3}{|l|}{ Less Democratic } \\
\hline Austria & Greenland & Panama & Afghanistan & Gabon & Nicaragua \\
\hline Argentina & Grenada & Papua New Guinea & Albania & Gambia & Niger \\
\hline Australia & Guyana & Paraguay & Algeria & Georgia & Nigeria \\
\hline Andorra & Hong Kong & Peru & Angola & Guatemala & North Korea \\
\hline Belgium & Hungary & Philippines & Armenia & Guinea & Oman \\
\hline Botswana & Iceland & Poland & Azerbaijan & Guinea-Bissau & Pakistan \\
\hline Brazil & India & Portugal & Bahrain & Haiti & Palestine \\
\hline Bulgaria & Indonesia & Romania & Bangladesh & Honduras & Qatar \\
\hline Canada & Ireland & Senegal & Belarus & Iran & Russia \\
\hline Cape Verde & Israel & Serbia & Benin & Iraq & Rwanda \\
\hline Chile & Italy & Singapore & Bhutan & Ivory Coast & Saudi Arabia \\
\hline Colombia & Jamaica & Slovakia & Bolivia & Jordan & Sierra Leone \\
\hline Costa Rica & Japan & Slovenia & $\begin{array}{l}\text { Bosnia } \\
\text { Hercegovina }\end{array}$ & Kazakhstan & Sudan \\
\hline Croatia & Kosovo & Somalia & Burkina Faso & Kenya & Swaziland \\
\hline Cyprus & Kiribati & South Africa & Burundi & Kuwait & Syria \\
\hline Czech Republic & Latvia & South Korea & Cambodia & Kyrgyzstan & Tajikistan \\
\hline Denmark & Lesotho & Spain & Cameroon & Laos & Tanzania \\
\hline Dominica & Lithuania & Sri Lanka & $\begin{array}{l}\text { Central African } \\
\text { Republic }\end{array}$ & Lebanon & Thailand \\
\hline $\begin{array}{l}\text { Dominican } \\
\text { Republic }\end{array}$ & Luxembourg & Suriname & Chad & Liberia & Togo \\
\hline Ecuador & Malaysia & Sweden & China & Libya & Turkey \\
\hline Estonia & Malta & Switzerland & Comoros & Macedonia & Turkmenistan \\
\hline Falkland Islands & Mauritius & Taiwan & $\begin{array}{l}\text { Congo } \\
\text { Brazzaville }\end{array}$ & Madagascar & Uganda \\
\hline Finland & Mexico & East Timor & Cuba & Malawi & Ukraine \\
\hline France & Mongolia & $\begin{array}{l}\text { Trinidad and } \\
\text { Tobago }\end{array}$ & $\begin{array}{l}\text { Dem. Rep. of } \\
\text { Congo }\end{array}$ & Mali & $\begin{array}{l}\text { United Arab } \\
\text { Emirates }\end{array}$ \\
\hline Germany & Namibia & Tunisia & Djibouti & Mauritania & Uzbekistan \\
\hline Ghana & Netherlands & United Kingdom & Egypt & Moldova & Vatican \\
\hline \multirow[t]{5}{*}{ Greece } & New Zealand & $\begin{array}{l}\text { United States of } \\
\text { America }\end{array}$ & El Salvador & Montenegro & Venezuela \\
\hline & Norway & Uruguay & $\begin{array}{l}\text { Equatorial } \\
\text { Guinea }\end{array}$ & Morocco & Vietnam \\
\hline & & & Eritrea & Mozambique & Yemen \\
\hline & & & Ethiopia & Myanmar & Zambia \\
\hline & & & Fiji & Nepal & Zimbabwe \\
\hline
\end{tabular}

Note. Political systems are defined based on the degree of democracy and classified using the 2019 Economist Intelligent Unit Democracy Index (EIU-DI). More democratic are full democracies plus flawed democracies. Less democratic includes hybrid regimes and authoritarian regimes. Political systems of countries not included in the EIU-DI were determined using data from the CIA World Factbook (CIA-WFB). These includes Greenland, Somalia, South Sudan, Falkland Islands, Vatican, Andorra, Western Sahara, and Kosovo. According the CIA WFB, the political systems of South Sudan is in transition. For this reason, it is not included in the list. Also excluded from the list is the disputed territory of Western Sahara. 
Table 2. Economic Systems (by country)

\begin{tabular}{|c|c|c|c|c|c|c|}
\hline \multicolumn{3}{|c|}{ Market Economy } & \multicolumn{2}{|c|}{ Command Economy } & \multicolumn{2}{|c|}{ Mixed Economy } \\
\hline Austria & Guyana & Slovakia & Afghanistan & Qatar & Albania & Lesotho \\
\hline Argentina & Hong Kong & Slovenia & Algeria & Palestine & Armenia & Liberia \\
\hline Australia & Iceland & South Africa & Angola & Russia & Azerbaijan & Macedonia \\
\hline Andorra & India & South Korea & Bahrain & Rwanda & Bangladesh & Madagascar \\
\hline Belgium & Ireland & Spain & Belarus & Somalia & Bhutan & Malawi \\
\hline Benin & Israel & Suriname & Burundi & Sudan & Bolivia & Malaysia \\
\hline Botswana & Italy & Sweden & Cambodia & Swaziland & $\begin{array}{l}\text { Bosnia } \\
\text { Herzegovina }\end{array}$ & Mali \\
\hline Brazil & Jamaica & Switzerland & $\begin{array}{l}\text { Cameroon } \\
\text { Central }\end{array}$ & Syria & Burkina Faso & Mexico \\
\hline Bulgaria & Japan & Taiwan & $\begin{array}{l}\text { African } \\
\text { Republic }\end{array}$ & Tajikistan & Colombia & Moldova \\
\hline Canada & Kiribati & East Timor & Chad & Thailand & Comoros & Montenegro \\
\hline Cape Verde & Latvia & $\begin{array}{l}\text { Trinidad and } \\
\text { Tobago }\end{array}$ & China & Turkey & Cuba & Morocco \\
\hline Chile & Lithuania & Tunisia & $\begin{array}{l}\text { Congo } \\
\text { Brazzaville }\end{array}$ & Turkmenistan & Djibouti & Mozambique \\
\hline Costa Rica & Luxembourg & $\begin{array}{l}\text { United } \\
\text { Kingdom }\end{array}$ & $\begin{array}{l}\text { Dem. Rep. of } \\
\text { Congo }\end{array}$ & $\begin{array}{l}\text { United Arab } \\
\text { Emirates }\end{array}$ & $\begin{array}{l}\text { Dominican } \\
\text { Republic }\end{array}$ & Myanmar \\
\hline Croatia & Malta & $\begin{array}{l}\text { United States } \\
\text { of America }\end{array}$ & Egypt & Uzbekistan & Ecuador & Nepal \\
\hline Cyprus & Mauritius & Uruguay & $\begin{array}{l}\text { Equatorial } \\
\text { Guinea }\end{array}$ & Venezuela & Fiji & Niger \\
\hline $\begin{array}{l}\text { Czech } \\
\text { Denmark }\end{array}$ & $\begin{array}{l}\text { Mongolia } \\
\text { Namibia }\end{array}$ & Vatican & $\begin{array}{l}\text { Eritrea } \\
\text { Ethiopia }\end{array}$ & $\begin{array}{l}\text { Vietnam } \\
\text { Yemen }\end{array}$ & $\begin{array}{l}\text { Gambia } \\
\text { Georgia }\end{array}$ & $\begin{array}{l}\text { Nigeria } \\
\text { Pakistan }\end{array}$ \\
\hline Dominica & Netherlands & & Gabon & & Ghana & $\begin{array}{l}\text { Papua New } \\
\text { Guinea }\end{array}$ \\
\hline $\begin{array}{l}\text { El Salvador } \\
\text { Estonia }\end{array}$ & $\begin{array}{l}\text { New Zealand } \\
\text { Norway }\end{array}$ & & $\begin{array}{l}\text { Iran } \\
\text { Iraq }\end{array}$ & & $\begin{array}{l}\text { Guatemala } \\
\text { Guinea }\end{array}$ & $\begin{array}{l}\text { Paraguay } \\
\text { Philippines }\end{array}$ \\
\hline $\begin{array}{l}\text { Falkland } \\
\text { Islands }\end{array}$ & Panama & & Kazakhstan & & Guinea-Bissau & Saudi Arabia \\
\hline Finland & Peru & & Laos & & Haiti & Serbia \\
\hline France & Poland & & Libya & & Honduras & Sierra Leone \\
\hline Germany & Portugal & & Mauritania & & Hungary & Singapore \\
\hline Greece & Romania & & Nicaragua & & Indonesia & Sri Lanka \\
\hline Greenland & Senegal & & North Korea & & Ivory Coast & Tanzania \\
\hline Grenada & & & Oman & & Jordan & Togo \\
\hline & & & & & Kenya & Uganda \\
\hline & & & & & Kosovo & Ukraine \\
\hline & & & & & Kuwait & Zambia \\
\hline & & & & & $\begin{array}{l}\text { Kyrgyzstan } \\
\text { Lebanon }\end{array}$ & Zimbabwe \\
\hline
\end{tabular}

Note. Economic system is defined based on the degree of individual or government involvement in economic decision making. Using the 2019 Freedom House Freedom in the World (FH-FIW) classification, countries are parsed into market economy (free), command economy (not free), and mixed economy (partially free). FH-FIW assigns each country and territory a score between 0 and 4 points on a series of 25 indicators, for an aggregate score of up to 100. These scores are used to determine two numerical ratings, for political rights and civil liberties, with a rating of 1 representing the most free conditions and 7 the least free. A country or territory's political rights and civil liberties ratings then determine whether it has an overall status of Free, Partly Free, or Not Free. Comoros, Fiji, and Hong Kong are not included in the FH-FIW index. Thus, we used data from globalEDGE to determine their economic systems. 
Table 3. Legal Systems (by country)

\begin{tabular}{|c|c|c|c|c|c|c|c|}
\hline \multirow{2}{*}{$\begin{array}{l}\begin{array}{l}\text { Commo } \\
\text { n Law }\end{array} \\
\text { Australia }\end{array}$} & \multirow{3}{*}{$\begin{array}{l}\text { Theocratic } \\
\text { Law }\end{array}$} & \multicolumn{3}{|l|}{ Civil Law } & \multicolumn{3}{|c|}{ Mixed Components } \\
\hline & & Albania & Germany & Serbia & Algeria & Jordan & Sri Lanka \\
\hline Andorra & & Angola & Greece & Slovakia & Bahrain & Kenya & Sudan \\
\hline Bhutan & Vatican & Argentina & Greenland & Slovenia & Bangladesh & Kuwait & $\begin{array}{l}\text { Swazilan } \\
\text { d }\end{array}$ \\
\hline Canada & & Armenia & Guatemala & Spain & Botswana & Lebanon & Syria \\
\hline $\begin{array}{l}\text { Dominic } \\
\text { a }\end{array}$ & & Austria & Haiti & Suriname & Burkina Faso & Lesotho & Taiwan \\
\hline $\begin{array}{l}\text { Falkland } \\
\text { Islands }\end{array}$ & & Azerbaijan & Honduras & Sweden & Burundi & Libya & Togo \\
\hline Fiji & & Belarus & Hungary & Switzerland & Cameroon & Madagascar & $\begin{array}{l}\text { Tunisia } \\
\text { United }\end{array}$ \\
\hline Ghana & & Belgium & Iceland & Tajikistan & Chad & Malaysia & $\begin{array}{l}\text { Arab } \\
\text { Emirates }\end{array}$ \\
\hline Grenada & & Benin & Italy & Thailand & China & Mali & Yemen \\
\hline $\begin{array}{l}\text { Hong } \\
\text { Kong }\end{array}$ & & Bolivia & Kazakhstan & Turkey & Comoros & Malta & $\begin{array}{l}\text { Zimbabw } \\
\text { e }\end{array}$ \\
\hline India & & $\begin{array}{l}\text { Bosnia } \\
\text { Herzegovin } \\
\text { a }\end{array}$ & Kosovo & $\begin{array}{l}\text { Turkmenista } \\
\mathrm{n}\end{array}$ & $\begin{array}{l}\text { Congo } \\
\text { Brazzaville }\end{array}$ & Mauritania & \\
\hline Ireland & & Brazil & Kyrgyzstan & Ukraine & Cyprus & Mauritius & \\
\hline Jamaica & & Bulgaria & Laos & Uruguay & $\begin{array}{l}\text { Dem. Rep. of } \\
\text { Congo }\end{array}$ & Mongolia & \\
\hline Kiribati & & Cambodia & Latvia & Uzbekistan & Djibouti & Morocco & \\
\hline Liberia & & Cape Verde & Lithuania & Venezuela & East Timor & $\begin{array}{l}\text { Mozambiqu } \\
\mathrm{e}\end{array}$ & \\
\hline Malawi & & $\begin{array}{l}\text { Central } \\
\text { African } \\
\text { Republic }\end{array}$ & $\begin{array}{l}\text { Luxembour } \\
\mathrm{g}\end{array}$ & Vietnam & Egypt & Namibia & \\
\hline $\begin{array}{l}\text { Myanma } \\
\mathrm{r}\end{array}$ & & Chile & Macedonia & & $\begin{array}{l}\text { Equatorial } \\
\text { Guinea }\end{array}$ & Niger & \\
\hline Nepal & & Colombia & Mexico & & Eritrea & Nigeria & \\
\hline $\begin{array}{l}\text { New } \\
\text { Zealand } \\
\text { Papua }\end{array}$ & & Costa Rica & Moldova & & Ethiopia & North Korea & \\
\hline $\begin{array}{l}\text { New } \\
\text { Guinea }\end{array}$ & & Croatia & Montenegro & & Gabon & Oman & \\
\hline $\begin{array}{l}\text { Sierra } \\
\text { Leone }\end{array}$ & & Cuba & Netherlands & & Gambia & Pakistan & \\
\hline Tanzania & & Czech & Nicaragua & & Guinea & Palestine & \\
\hline $\begin{array}{l}\text { Trinidad } \\
\text { and } \\
\text { Tobago }\end{array}$ & & Denmark & Norway & & $\begin{array}{l}\text { Guinea-Bissa } \\
\mathrm{u}\end{array}$ & Philippines & \\
\hline Uganda & & $\begin{array}{l}\text { Dominica } \\
\text { Republic }\end{array}$ & Panama & & Guyana & Qatar & \\
\hline $\begin{array}{l}\text { United } \\
\text { Kingdo } \\
\text { m } \\
\text { United }\end{array}$ & & Ecuador & Paraguay & & Indonesia & Rwanda & \\
\hline $\begin{array}{l}\text { States of } \\
\text { America }\end{array}$ & & El Salvador & Peru & & Iran & Senegal & \\
\hline Zambia & & $\begin{array}{l}\text { Estonia } \\
\text { Finland }\end{array}$ & $\begin{array}{l}\text { Poland } \\
\text { Portugal }\end{array}$ & & $\begin{array}{l}\text { Iraq } \\
\text { Israel }\end{array}$ & $\begin{array}{l}\text { Singapore } \\
\text { Somalia }\end{array}$ & \\
\hline & & France & Romania & & Ivory Coast & $\begin{array}{l}\text { South } \\
\text { Africa }\end{array}$ & \\
\hline & & Georgia & Russia & & Japan & South Korea & \\
\hline
\end{tabular}

Note. The legal systems classification is based on a reclassification of JuriGlobe's five legal systems into common law, civil law, theocratic (religious) law, and mixed law systems. Common law is based on tradition, precedent, and custom. Common law includes customary law. Theocratic law is a legal system predominantly based on religious teachings. Civil law is based on detailed set of laws organized into codes. Mixed law systems refers to a combination of two or more of the other legal systems. Table A1 in the Appendix summarizes the mixed systems components. JuriGlobe database contained no information about the legal system of Kosovo. The information is thus obtained from the European Union Rule of Law Mission. 


\subsection{Summary of Political, Economic, and Legal Systems}

Table 4 summarizes the different types of political, economic, and legal systems described in Sections 2.1 to 2.3. These are the two political systems (more democratic and less democratic), three economic systems (market, command, and mixed), and four legal systems (common, civil, theocratic, and mixed components).

Table 4. Political, Economic, and Legal Systems Summary

\begin{tabular}{lll}
\hline Political Systems & Economic Systems & Legal Systems \\
\hline More Democratic & Market Economy & Common Law \\
Less Democratic & Mixed Economy & Theocratic Law \\
& Command Economy & Civil Law \\
& & Mixed Components \\
\hline
\end{tabular}

Note. Political systems are defined based on the degree of democracy and classified using the 2019 Economist Intelligent Unit Democracy Index. More democratic are full democracies plus flawed democracies. Less democratic includes hybrid regimes and authoritarian regimes. Economic system is defined based on the degree of individual or government involvement in economic decision making. Using the 2019 Freedom House Freedom in the World (FH-FIW) classification, countries are parsed into market economy (free), command economy (not free), and mixed economy (partially free). The legal systems classification is based on a reclassification of JuriGlobe's five legal systems into common law, civil law, theocratic (religious) law, and mixed law systems. Common law is based on tradition, precedent, and custom. Common law includes customary law. Theocratic law is a legal system predominantly based on religious teachings. Civil law is based on detailed set of laws organized into codes. Mixed law systems refers to a combination of two or more of the other legal systems.

\section{Methodology and Results}

Having carefully delineated the different types of political, economic, and legal systems in the previous section, the study proceeds to classify countries into composite groups. A simple classification system is implemented; one that combines each of the political system with all other economic and legal systems to classify countries. More specifically, with 2 political systems, 3 economic systems, and 4 legal systems, the study identified 24 variant combinations. These variant combinations are referred to as types, with Type 1 representing the least risky political economy conditions and Type 24 the most risky political economy conditions. Table 5 shows each of the 24 types with their corresponding countries.

Type 1 countries are more democratic, lean towards market economy, and operate on common law system. Also, they are mostly technology-driven. Type 1 countries include Australia, Canada, Ireland, New Zealand, United Kingdom, United States, Hong Kong, India, and few islands in the Caribbean and Virgin Islands regions. These countries are of the least risk politically, economically, and legally for international business investments. Type 1's polar opposite is Type 24 countries who are less democratic, lean towards command economy, and operate on mixed legal systems. Type 24 countries are quite diverse and include Algeria, Bahrain, Burundi, Cameroon, Central Africa Republic, Chad, China, Congo Brazzaville, Democratic Rep. of Congo, Egypt, Eritrea, Ethiopia, Gabon, Guinea-Bissau, Libya, Mauritania, North Korea, Qatar, Rwanda, Sudan, Swaziland, Syria, Equatorial Guinea, United Arab Emirates (UAE), and Yemen. Except for Bahrain, China, Qatar, UAE, Swaziland, and Cameroon, all Type 24 countries have, at least, in the last decade experienced political instability that have stifled economic growth and thrown their legal systems into disarray making them extremely risky for international business investments. The situation is however changing in Egypt, with a new government and Rwanda with the rise of Paul Kagame as an international hero for reforming the country and making it one of the most attractive FDI destinations in Africa. Other countries, such as North Korea, though it has not experienced political instability, is known for its notorious authoritarian regime. Also, geographically, unlike Type 1 countries that are concentrated in the northern hemisphere, Type 24 countries are spread all over the world.

Between the two extremes are different interesting combinations that includes, for example, Type 11 countries Colombia, Dominican Republic, Serbia, Hungary, Kosovo, Ecuador, Paraguay, and Mexico - that are more democratic, maintain a mixed economic system, and run on civil law. The political economy of these countries are not the best but they are not the worst either. Also, there are Type 3 countries that are more democratic, operate on market economy and a civil law system. Type 3 contains the largest share of countries: one-fifth of the 176 total. These countries are Argentina, Austria, Belgium, Brazil, Bulgaria, Cape Verde, Chile, Costa Rica, Croatia, Czech Republic, Denmark, Estonia, Finland, France, Germany, Greece, Greenland, Iceland, Italy, Latvia, 
Lithuania, Luxembourg, Netherlands, Norway, Panama, Peru, Poland, Portugal, Romania, Slovakia, Slovenia, Spain, Suriname, Sweden, Switzerland, and Uruguay. Type 3 countries are similar to Type 1 countries in so many respects. However, the principal difference is that Type 3 countries are mostly located in Europe and operate on the civil legal system. Furthermore, though risk factors of Types 1 and 3 do not differ much, international investors looking for countries with less litigation costs may want to consider Type 3 countries since their codified legal system makes their laws relatively clear and precise.The full disclosure not only reduces investor uncertainty but also allow investors to be fully aware of ramifications of the laws.

Also similar to Type 1 is Type 9 countries which include Ghana and Papua New Guinea. These countries are more democratic, maintain mixed economy, and operate on common legal system. Their principal risk factor is strong government presence in the economy. While Ghana could also qualify as Type 1 country because Freedom House FIW classification places it under free market economy, Ghana's economy is at best a mixed economy. Indeed, our closer examination of Ghana reveal that the degree of government intervention is quite strong. For instance, the price of goods and services in the country are heavily dictated by the price of petroleum products. The government sets the price of petroleum products and the price of everything else follows accordingly. In 2005, Ghana initiated a petroleum price deregulation policy but till date the government maintains significant control in the pricing of petroleum products. Consequently, we classify Ghana as Type 9 country and not Type 1.

Another interesting group is Type 14, i.e., countries that are less democratic, lean towards market economy, and operate on theocratic laws. Only one country, the Vatican, fits this category. Type 14's counterpart is Type 22 countries who are also less democratic and operate on theocratic laws but maintain a command economic system. These countries are Afghanistan and Saudi Arabia. Risk factors for Afghanistan are however much higher compared to Vatican and Saudi Arabia. Yet another intriguing group is Type 23 countries. These are less democratic, maintain command economy, and mixed components legal system. They also share very similar characteristics to Type 24. However, a main difference is that unlike Type 24 countries, almost all Type 23 countries are oil producing countries heavily concentrated in Central Asia (Uzbekistan, Kazakhstan, Tajikistan, and Turkmenistan) and Eastern Europe (Russia, Belarus, and Moldova). Few Type 23 countries are in Latin America (Nicaragua and Venezuela) and Africa (Angola). The political economy of these oil export-dependent countries is extremely risky and corrupt, but it is unclear whether the presence of oil drives the political economy risks and corruption or whether the political economy risks and corrupt practices are inherent in the cultures of these countries.

Other types with wide dispersion of countries all over the world are Types 4, 12, 19, and 20. For instance, Type 4 countries are more democratic, run on market economy but maintain a mixed legal system. It includes countries such as Botswana, Mauritius, Namibia, Senegal, South Africa, and Tunisia (Africa); Cyprus (Europe); Israel (Middle East); and India, Japan, Mongolia, South Korea, Taiwan, and East Timor (Asia). Type 20 countries on the other hand are less democratic with mixed economy and mixed legal system includes Jordan, Kuwait, Lebanon, and Palestine (Middle East), Bangladesh, and Pakistan (Asia), and Burkina Faso, Comoros, Ivory Coast, Djibouti, Gambia, Guinea, Kenya, Madagascar, Mali, Morocco, Mozambique, Niger, Nigeria, Togo, and Zimbabwe (Africa). Political economy risk factors for Type 4 and Type 20 countries originates from occasional commodity price shocks, persistent red-taped legal practices, and diversified religious practices although these risk factors are more heightened in Type 20 countries than in Type 4 countries.

Some country types do not contain any country. These include Types 5 to 7 , all of which combines democratic political system with command economic system, and different legal systems. In theory, democratic political systems are incompatible with command market economy. However, in practice it is likely to have cases where a more democratic country operates under a pseudo-command economy especially during periods of extraordinary circumstances. A case in point is the United States during the 1970s oil crisis when government took a strong role in the economy by rationing several basic necessities and directing private enterprises (Baumeister and Kilian 2016; Gray 1987; DeLong 1997; Ibrahim 1990). In 2018, no country experienced such extraordinary circumstances which perhaps explain why there are no entries in Types 5 to 7 . The other exception to the incompatibility principle between democratic political system and command economic system is Somalia, a Type 8 country, which recently became a democratic country after several years of civil war but still maintains a command economy due to the fragile state of the economy. Other types that contain no country or a set of countries are Type 2 (more democratic, market economy, theocratic law); Type 10 (more democratic, mixed economy, theocratic law); Type 13 (less democratic, mixed economy, common law); Type 16 (less democratic, market economy, mixed components legal system); and Type 18 (less democratic, market economy, theocratic law). While Types $2,10,13,16$, and 18 contain plausible combinations of systems but currently do not have 
countries that fit into them, it is conceivable that in future iterations of this new classification system some country may fall into one of these types.

Table 5. Types with Corresponding Countries

\begin{tabular}{|c|c|}
\hline Type & Countries \\
\hline Type 1 (MD, ME, CML) & $\begin{array}{l}\text { Australia, Andorra, Dominica, Falkland Islands, Grenada, Hong Kong, India, Ireland, } \\
\text { Jamaica, Kiribati, New Zealand, Canada, Trinidad and Tobago, United Kingdom, United } \\
\text { States of America. }\end{array}$ \\
\hline Type 2 (MD, ME, TCL) & None. \\
\hline Type 3 (MD, ME, CVL) & $\begin{array}{l}\text { Argentina, Austria, Belgium, Brazil, Bulgaria, Cape Verde, Chile, Costa Rica, Croatia, } \\
\text { Czech Republic, Denmark, Estonia, Finland, France, Germany, Greece, Greenland, Iceland, } \\
\text { Italy, Latvia, Lithuania, Luxembourg, Netherlands, Norway, Panama, Peru, Poland, } \\
\text { Portugal, Romania, Slovakia, Slovenia, Spain, Suriname, Sweden, Switzerland, Uruguay. }\end{array}$ \\
\hline Type 4 (MD, ME, MXC) & $\begin{array}{l}\text { Botswana, Cyprus, East Timor, Guyana, Israel, Japan, Malta, Mauritius, Mongolia, } \\
\text { Namibia, Senegal, South Africa, South Korea, Taiwan, Tunisia. }\end{array}$ \\
\hline Type 5 (MD, CE, CML) & None. \\
\hline Type 6 (MD, CE, TCL) & None. \\
\hline Type 7 (MD, CE, CVL) & None. \\
\hline Type 8 (MD, CE, MXC) & Somalia \\
\hline Type 9 (MD, MXE, CML) & Ghana, Papua New Guinea. \\
\hline Type 10 (MD, MXE, TCL) & None. \\
\hline Type 11 (MD, MXE, CVL) & Colombia, Dominican Republic, Ecuador, Hungary, Mexico, Kosovo, Paraguay, Serbia. \\
\hline Type $12(\mathrm{MD}, \mathrm{MXE}, \mathrm{MXC})$ & Indonesia, Lesotho, Malaysia, Philippines, Singapore, Sri Lanka. \\
\hline Type 13 (LD, ME, CML) & None. \\
\hline Type 14 (LD, ME, TCL) & Vatican \\
\hline Type 15 (LD, ME, CVL) & Benin, El Salvador. \\
\hline Type 16 (LD, ME, MXC) & None. \\
\hline Type 17 (LD, CE, CML) & Fiji \\
\hline Type 18 (LD, CE, TCL) & None. \\
\hline Type 19 (LD, CE, CVL) & $\begin{array}{l}\text { Albania, Armenia, Azerbaijan, Bolivia, Bosnia Herzegovina, Cuba, Georgia, Guatemala, } \\
\text { Haiti, Honduras, Kyrgyzstan, Macedonia, Moldova, Montenegro, Ukraine. }\end{array}$ \\
\hline Type 20 (LD, CE, MXC) & $\begin{array}{l}\text { Bangladesh, Burkina Faso, Comoros, Djibouti, Gambia, Guinea, Iran, Iraq, Ivory Coast, } \\
\text { Jordan, Kenya, Kuwait, Lebanon, Madagascar, Mali, Morocco, Mozambique, Niger, } \\
\text { Nigeria, Oman, Pakistan, Palestine, Togo, Zimbabwe. }\end{array}$ \\
\hline Type 21 (LD, MXE, CML) & Bhutan, Liberia, Malawi, Myanmar, Nepal, Sierra Leone, Tanzania, Uganda, Zambia. \\
\hline Type 22 (LD, MXE, TCL) & Afghanistan, Saudi Arabia. \\
\hline Type 23 (LD, MXE, CVL) & $\begin{array}{l}\text { Angola, Belarus, Cambodia, Kazakhstan, Laos, Nicaragua, Russia, Tajikistan, Thailand, } \\
\text { Turkey, Turkmenistan, Uzbekistan, Venezuela, Vietnam. }\end{array}$ \\
\hline Type 24 (LD, MXE, MXC) & $\begin{array}{l}\text { Algeria, Bahrain, Burundi, Cameroon, Central Africa Republic, Chad, China, Congo } \\
\text { Brazzaville, Democratic Rep. of Congo, Egypt, Eritrea, Ethiopia, Gabon, Guinea-Bissau, } \\
\text { Libya, Mauritania, North Korea, Qatar, Rwanda, Sudan, Swaziland, Syria, Equatorial } \\
\text { Guinea, United Arab Emirates, Yemen. }\end{array}$ \\
\hline
\end{tabular}

Note. Type is a scale that combines political, economic, and legal systems of countries to rate the associated political economy risks of doing business. The scale is from Type 1 (least risky) to Type 24 (highly risky). Political systems consist of More Democratic (MD) and Less Democratic (LD). Economic systems comprise of Market Economy (ME), Command Economy (CE), and Mixed Economy (MXE). Legal systems consist of Common Law (CL), Theocratic Law (TCL), Civil Law (CVL), and Mixed Components (MXC). Political systems are defined based on the degree of democracy and classified using the 2019 Economist Intelligent Unit Democracy Index. More democratic are full democracies plus flawed democracies. Less democratic includes hybrid regimes and authoritarian regimes. Economic system is defined based on the degree of individual or government involvement in economic decision making. Using 2019 Freedom House Freedom in the World (FH-FIW) classification, countries are parsed into market economy (free), command economy (not free), and mixed economy (partially free). The legal systems classification is based on a reclassification of JuriGlobe's five legal systems into four: common law, theocratic/religious law, civil law, and mixed components. Common law is based on tradition, precedent, and custom. Common law includes customary law. Theocratic law is a legal system predominantly based on religious teachings. Civil law is based on detailed set of laws organized into codes. Mixed components refer to a combination of two or more of the other legal systems.

\section{Conclusion}

Political economy risks associated with conducting international business abound and are difficult to measure or classify in a consistent manner. Existing classification systems are fragmented and often fraught with inconsistencies leaving investors and multinational businesses scrambling for information from copious sources to determine the nature of political economy risks associated with doing business in different countries. The 
search of information from prodigious sources is not just inefficient but also expensive to investors and multinational businesses. This paper proposes a new composite country classification system that rates the political economy risks associated with doing business in countries all over the world. It is intended to provide investors and multinational companies a quick and efficient way of gauging the extent of political economy risks for the purpose of conducting international business.

The new system classifies countries into types, a rating scale that combines political, economic, and legal systems of countries to rate the associated political economy risks. The new system is operationalized using 2018 data on 176 countries. Twenty-four country types were identified. At the extremes are Type 1 countries (least risky) and Type 24 countries (most risky). Type 1 countries are more democratic, lean towards market economy, and operate on common law system whereas Type 24 countries are less democratic, lean towards command economy, and operate on mixed legal systems. On the spectrum between these two polar opposites are different intriguing combinations that includes, for example, countries that are more democratic, run on command economy and mixed legal systems (Type 8) and countries that are more democratic, maintain a mixed economy, and operate on civil law (Type 11). There are also Type 14 countries that are less democratic, lean towards market economy, and operate on theocratic laws; Type 15 countries that are less democratic, lean towards market economy, and run on civil law; Type 20 countries that are less democratic, operate on mixed economy and mixed legal system; and several other types.

Taken together, the results from this new classification suggest that political economy risks associated with doing international business are relatively mild in Type 1, Type 3, and Type 4 countries. However, international businesses should temper their investment decisions with caution in Type 19, Type 20, Type 22, Type 23, and Type 24 countries due to high political, economic, and legal risks, especially Types 23 and 24 where these risks are excessive. At the same time, international businesses may want to refocus their attention to countries hitherto considered extremely risky and volatile for business but now have become havens for international investments due to drastic reduction in political, economic, and legal risks associated with doing business in those countries. Most of these countries are Type 11 countries. The results are descriptively valid because they represent the factual accuracy of the political, economic, and legal risks associated with doing business in different countries. In addition, the results satisfy conceptual validity because the conceptual framework and explanations developed from the study fits the data and are, therefore, credible and defensible. We should note however that while the twenty-four country types identified in this new classification system are time-invariant, countries may move up or down due to improvements or deteriorations in certain aspects of their political economy. Thus, a dedicated website accompanies this paper that updates the country list in all the twenty-four types on an annual basis.

\section{Acknowledgments}

The authors are very grateful to the editor, two anonymous referees, and Saani Mohammed for their helpful comments on the earlier version of the paper.

\section{References}

Ball, A. R. (1988). Classification of governments. In Modern Politics and Government. Palgrave: London. https://doi.org/10.1007/978-1-349-19347-9_3

Baumeister, C., \& Kilian, L. (2016). Forty years of oil price fluctuations: Why the price of oil may still surprise us. Journal of Economic Perspectives, 30, 139-160. https://doi.org/10.1257/jep.30.1.139

Brooker, P. (2000). Non-Democratic regimes: Theory, government, and politics. St. Martin's Press: New York.

Bruno, D., \& Richmond, H. (2003). The truth about taxonomies. Information Management Journal, 37(2), 44-53.

CIA World Factbook. (2019). Central Intelligence Agency. Retrieved from https://www.cia.gov/index.html

Collier, D., \& Adcock, R. (1999). Democracy and dichotomies: A pragmatic approach to choices about concepts. Annual Review of Political Science, 2, 537-565. https://doi.org/10.1146/annurev.polisci.2.1.537

DeLong, J. B. (1997). Americas only peacetime inflation: the 1970s. In Christina, R., \& David, R. (Eds.), Reducing Inflation, NBER Studies in Business Cycles (Vol. 30).

Economist Intelligence Unit. (2019). Democracy index 2018: Me Too? Political participation, protest and democracy. Retrieved from: https://www.eiu.com/public/topical_report.aspx? campaignid=Democracy2018

European Union Rule of Law Mission. (2018). In-Depth Assessment Report of the Judicial System in Kosovo. EULEX Kosovo. Retrieved from https://rm.coe.int/in-depth-assessment-report-of-the-judicial-system/16807828e6 
Freedom House. (2019). Freedom in the world: Democracy in retreat. Retrieved from https://freedomhouse.org/report/freedom-world/freedom-world-2019

GlobalEDGE. (2019). Country Insights. Retrieved from https://globaledge.msu.edu/global-insights/by/country

Gomez, E. T., \& Jomo, K. S. (1999). Malaysia's political economy: Politics, patronage and profits. Cambridge University Press.

Gray, W. B. (1987). The cost of regulation: OSHA, EPA, and the productivity slowdown. American Economic Review, 77(5), 998-1006.

Haggard, S. (2000). The political economy of the Asian financial crisis. Washington, DC: Institute for International Economics. https://doi.org/10.1080/096922900346947

Hamilton, L., \& Webster, P. (2018). The international business environment (4th ed.). New York: Oxford University Press.

Heilbroner, R., \& Boettke, B. J. (2018). Economic systems. Retrieved from https://www.britannica.com/topic/economic-system

Henisz, W. J., \& Zelner, B. A. (2003). The strategic organization of political risks and opportunities. Strategic Organization, 1(4), 451-460. https://doi.org/10.1177/14761270030014005

Heslop, D. A. (2018). Political systems. Encyclopedia Britannica. Retrieved from https://www.britannica.com/topic/political-system

Hill, C. W. (2016). International business: Competing in the global marketplace (11th ed.). McGraw-Hill Education.

Ibrahim, I. B., \& Hurst, C. (1990). Estimating energy and oil demand functions. Energy Economics, 13(2), 93-102. https://doi.org/10.1016/0140-9883(90)90042-E

JuriGlobe Research Group. (2019). University of Ottawa. Retrieved from http://www.juriglobe.ca/eng/

Sjuggerud, M. (2018). Looking at legal systems around the world. Retrieved from https://www.hmtlaw.com/International-Business/Legal-Systems-Of-The-World.shtml

USC Law Library. (2019). Guide to International and Foreign Law Research. Retrieved from https://guides.law.sc.edu/internationallaw

\section{Notes}

Note 1. For a full description of the EIU-DI methodology, see Economist Intelligence Unit (2019).

Note 2. For a full description of the FH-FIW methodology, see Freedom House (2019).

Note 3. Detailed composition of mixed components legal systems by country is provide in Table A1 in the Appendix. JuriGlobe database contained no information about the legal system of Kosovo. The information is thus obtained from the European Union Rule of Law Mission (2018). 


\section{Appendix}

Table A1. Mixed Components Legal System

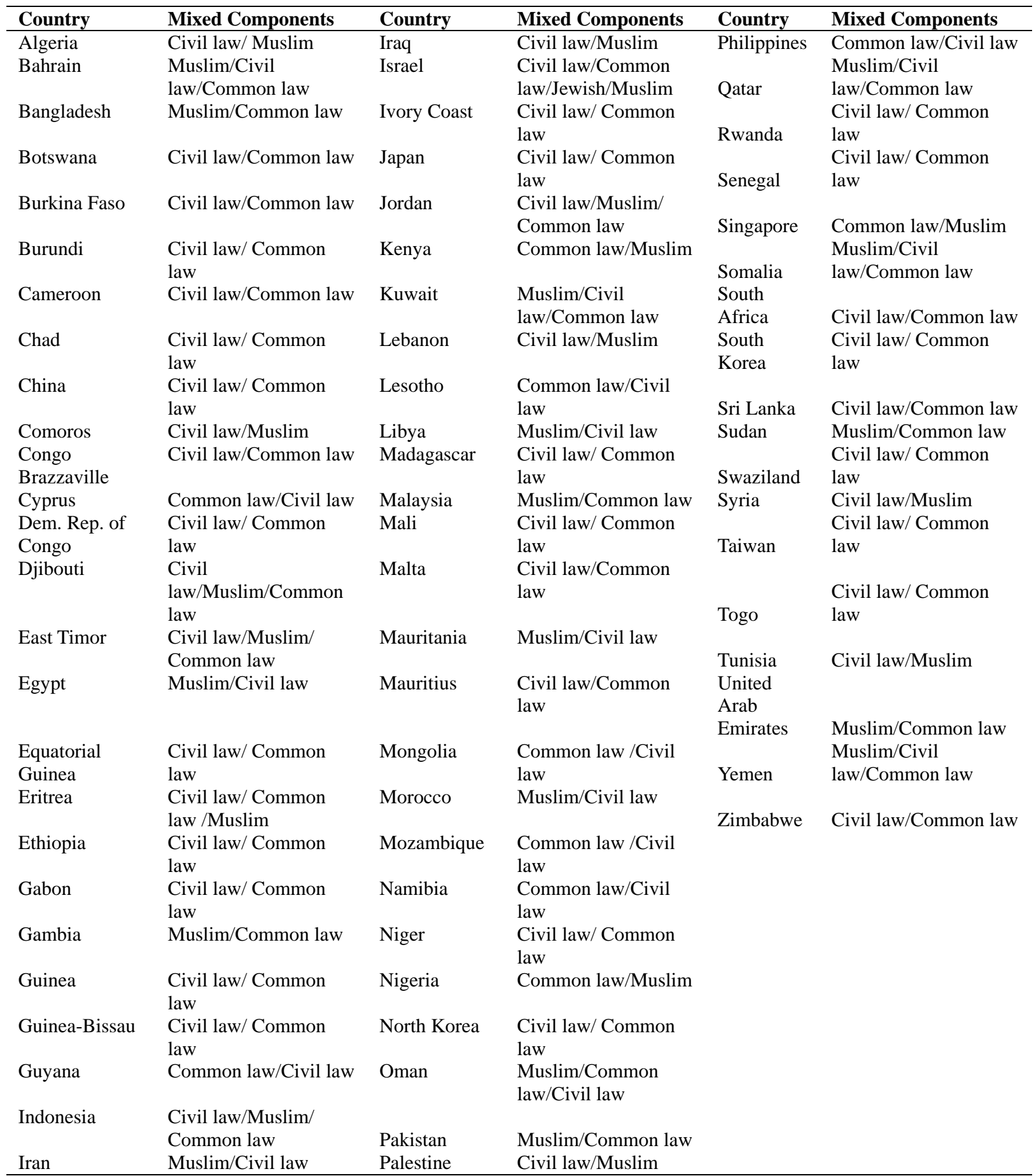

Note. Mixed law systems is the fourth legal system and refers to a combination of two or more of the other three legal systems, i.e., common law, civil law, and theocratic law.

\section{Copyrights}

Copyright for this article is retained by the author(s), with first publication rights granted to the journal.

This is an open-access article distributed under the terms and conditions of the Creative Commons Attribution license (http://creativecommons.org/licenses/by/4.0/). 